\title{
PENGARUH COURTESY, DAYA TANGGAP DAN KEPUASAN NASABAH TERHADAP LOYALITAS NASABAH BMT ASSYAFI'IYAH CABANG PURBOLINGGO LAMPUNG TIMUR
}

\author{
Durotun Nasikah ${ }^{1}$, Suwarto $^{2}$ \\ Universitas Muhammadiyah Metro ${ }^{1,2}$ \\ durotunnasika82@gmail.com ${ }^{1}$,wartok.umm@yahoo.co.id ${ }^{2}$
}

\begin{abstract}
ABSTRAK
Penelitian ini bertujuan untuk mengetahui pengaruh langsung courtesy, daya tanggap, dan kepuasan nasabah terhadap loyalitas nasabah. Jenis penelitian yang digunakan yaitu penelitian kuantitatif. Metode penelitian ini dilakukan dengan 85 responden yang diambil dengan accidental sampling dan kuesioner sebagai instrumen penelitian. Hasil penelitian ini yaitu 1) courtesy berpengaruh langsung positif terhadap loyalitas nasabah, 2) daya tanggap berpengaruh langsung positif terhadap loyalitas nasabah, 3) kepuasan nasabah berpengaruh langsung positif terhadap loyalitas nasabah, 4) courtesy berpengaruh langsung positif terhadap kepuasan nasabah, 5) daya tanggap berpengaruh langsung positif terhadap kepuasan nasabah.
\end{abstract}

Kata-kata kunci: courtesy, daya tanggap, kepuasan nasabah dan loyalitas nasabah.

\section{THE EFFECT OF COURTESY, RESPONSIBILITY AND CUSTOMER SATISFACTION ON CUSTOMER LOYALTY OF BMT ASSYAFI'IYAH PURBOLINGGO BRANCH EAST LAMPUNG}

\begin{abstract}
The aim of this research were to determine the effect of courtesy, Responsiveness, and customer satisfaction on customer loyalty. The quantitative approach is implemented in this research. The method of research surveys on 85 customers is taken by accidental sampling and questionnaire as an instrument of research. Findings signify that: 1) courtesy direct effect positively to customer loyalty, 2) Responsiveness direct effect positively to customer loyalty, 3) customer satisfaction direct effect positively to customer loyalty, 4) courtesy direct effect positively to customer satisfaction, 5) Responsiveness direct effect positively to customer satisfaction.
\end{abstract}

Keyword: Courtesy, Responsiveness, customer satisfaction and customer loyalty

\section{PENDAHULUAN}

Suatu usaha dapat mencapai perusahaan dapat membangun loyalitas keunggulan kompetitif dapat melalui hubungan jangka panjang antara perusahaan dengan pelanggan dan

kepada pelanggannya.

Loyalitas nasabah merupakan puncak dari pencapaian suatu bisnis. 
Nasabah yang puas dan setia tidak akan ragu untuk menyebarkan kebaikan mengenai produk perbankan yang dikonsumsinya. Besarnya loyalitas pelanggan atau nasabah tidak lepas dari besarnya kepuasan pelanggan atau nasabah. Seperti pendapat $\mathrm{Hu}$ \& Huang (2011) menyatakan bahwa loyalitas pelanggan sangat dipengaruhi oleh kepuasan layanan pelanggan dan menunjukkan bahwa kepuasan pelanggan adalah faktor penting yang akan meningkatkan loyalitas pelanggan. Srivastava dan Rai (2018) mendefinisikan loyalitas pelanggan sebagai sejauh mana pelanggan telah terlibat dalam pembelian kembali layanan perusahaan khusus selama beberapa tahun terakhir dan pentingnya porsi pengeluaran pelanggan dengan mengacu pada pengeluaran totalnya dalam kategori layanan tersebut. Oleh sebab itu perusahaan atau badan usaha yang telah memperoleh pelanggan atau nasabah yang loyal maka harus dipertahankan.

Salah satu faktor yang mempengaruhi loyalitas nasabah adalah courtesy. Courtesy dapat diartikan sebagai kesopanan atau menjaga hubungan dengan baik. Sedangkan pendapat lain Eisenberg, et al (2018) mengatakan bahwa Sopan santun terdiri dari perilaku yang termasuk menginformasikan karyawan lain sebelum keputusan yang dapat mempengaruhi mereka. Menurut Yin et al (2018) kesopanan mengacu pada cara memperlakukan orang lain dengan saling menghormati, memberikan informasi yang tepat kepada orang lain, dan mendistribusikan informasi dan detail kepada orang lain yang membutuhkan. Memberikan informasi yang jelas dan detail akan mencegah dari kesalahpahaman dan konflik di tempat kerja. Faktor yang dapat mempengaruhi loyalitas nasabah selain courtesy yaitu daya tanggap. Muhamad, et al (2013) berpendapat bahwa daya tanggap mengacu pada kemauan umum untuk membantu pelanggan dan memberikan layanan yang cepat, yang mengacu pada kemampuan menanggapi kebutuhan pelanggan individu dan menunjukkan minat yang tulus dalam pemecahan masalah.

Kepuasan adalah evaluasi pelanggan terhadap produk atau layanan dalam hal kemampuan mereka dalam memenuhi kebutuhan dan keinginan pelanggan (Setiawan \& Sayuti 2017).

Menurut Rizan (2014) pelanggan akan melakukan pembelian ulang dan merekomendasikan kepada orang lain jika pelanggan tersebut merasakan hubungan timbal balik antara pelanggan dengan penyedia layanan. Berbeda dengan pendapat yang dikemukakan oleh Leninkumar (2017) pelanggan akan merekomendasikan layanan perusahaan 
kepada orang lain apabila pelanggan percaya dengan penyedia jasa sehingga dia merasa puas dengan layanan yang didapat.

Berdasarkan latar belakang diatas, maka rumusan masalah dalam penelitian ini adalah (1) Apakah courtesy berpengaruh langsung positif terhadap loyalitas nasabah? (2) Apakah Daya Tanggap berpengaruh langsung positif terhadap loyalitas nasabah? (3) Apakah kepuasan nasabah berpengaruh langsung positif terhadap loyalitas nasabah? (4) Apakah courtesy berpengaruh langsung positif terhadap kepuasan nasabah? (5) Apakah Daya Tanggap berpengaruh langsung positif terhadap kepuasan nasabah?

Loyalitas pelanggan merupakan puncak dari pencapaian tujuan suatu perusahaan. Loyalitas pelanggan tidak hanya memastikan pembelian berulang dan publisitas positif dengan nilai yang lebih besar dalam hal keandalan, itu juga mengarah pada sejumlah manfaat signifikan lainnya seperti niat beli silang, preferensi berdasarkan prioritas dan eksklusif kepada perusahaan dan produk / layanannya, bagian yang lebih besar dari dompet dan sebagainya yang memberikan keunggulan kompetitif bagi perusahaan (Rai \& Medha, 2013). Suharto \& Ardhiansyah (2019) menjelaskan loyalitas pelanggan dapat digambarkan sebagai bentuk hubungan yang baik antara pelanggan dan perusahaan atau organisasi yang berhubungan dengan kebutuhan mereka sehingga pelanggan melakukan transaksi berulang.

Perusahaan yang memberikan pelayanan yang baik seperti karyawan yang menjaga sopan santun dalam pelayanannya serta tanggap dalam merespon permintaan pelanggan maka akan menimbulkan kepercayaan sehingga pelanggan akan puas dan akan kembali menggunakan produk yang ditawarkan.

Courtesy dapat diartikan sebagai sikap sopan santun yang dapat mencegah suatu masalah atau konflik di tempat kerja. Menurut Tambe \& Shanker (2014) sopan santun mengacu pada membantu orang lain untuk mencegah masalah antar pribadi, seperti berkonsultasi dengan orang lain sebelum mengambil tindakan apa pun yang akan mempengaruhi mereka. Getahun (2018) mengemukakan sopan santun mencakup upaya sebelumnya yang dilakukan untuk mencegah masalah dengan orang lain dan tidak menyalahgunakan hak orang lain. Saling menghormati sesama karyawan diperlukan untuk mencegah konflik yang terjadi sehingga dapat menumbuhkan suasana yang harmonis dan berdampak pada kenyamanan yang dirasakan pelanggan dan pelanggan akan terdorong untuk terus menggunakan produk 
atau jasa dari perusahaan tersebut. Cavus (2017) mendeskripsikan sopan santun yaitu memiliki keterampilan komunikasi yang tinggi adalah cara untuk sukses dan koordinasi untuk suatu organisasi. Sedangkan menurut Ozdemir \& Ergun (2015) sopan santun dapat diartikan kecenderungan untuk berkonsultasi dengan orang lain dan menggabungkan perspektif sebelum mengambil tindakan.

Daya Tanggap merupakan salah satu dari dimensi kualitas pelayanan. AlAzzam (2015) mendefinisikan responsiveness diartikan sebagai kesediaan atau kesiapan pegawai untuk memberikan pelayanan. Ini berisi ketepatan waktu layanan. Pendapat yang dikemukakan oleh Omar, et al (2016) responsiveness mengacu pada kesediaan penyedia layanan untuk memberikan layanan yang cepat dan membantu pelanggan. Dimensi ini menekankan kecepatan dan ketepatan dalam berurusan dengan pertanyaan, permintaan, masalah, dan keluhan pelanggan. Karyawan yang menunjukkan sikap baik dalam memberikan pelayanan terhadap pelanggan sehingga tercapai kepuasannya maka pelanggan akan menunjukkan loyalitas terhadap perusahaan tersebut. Fellix (2017) mengatakan responsiveness dapat diartikan Pelayanan yang cepat kepada pelanggan, kesediaan untuk membantu pelanggan, kesiapan untuk menanggapi permintaan pelanggan, dan karyawan akan menanamkan kepercayaan pada pelanggan. Menurut Othman et al, (2019) responsiveness adalah kesiapan atau kesediaan karyawan dalam memberikan pelayanan kepada pelanggan. Ini melibatkan ketepatan waktu layanan. Kecepatan dan ketepatan karyawan dalam rangka memenuhi kebutuhan pelanggan dapat berpengaruh pada purna beli sehingga konsumen akan menjadi lebih puas dan lebih tertarik untuk kembali untuk menggunakan jasa tersebut.

Menurut Basari \& Shamsudin (2020) kepuasan pelanggan adalah suatu keadaan dimana pelanggan merasa puas, baik terhadap kualitas produk maupun keseluruhan interaksi yang dialami oleh pelanggan. Kepuasan pelanggan mengacu pada penerapan beberapa prosedur untuk menjembatani kesenjangan yang ada antara kebutuhan dan harapan klien dan produk dan layanan yang tersedia (Al-Mhasnah et al, 2018). Kepuasan diartikan sebagai kondisi afektif konsumen yang dihasilkan dari evaluasi global semua aspek yang membentuk hubungan konsumen (Abd Ghani et al, 2017). Pelanggan yang puas dengan jasa yang diberikan oleh perusahaan cenderung akan memberikan informasi kepada orang lain atas jasa sudah dirasakan 
bahwa jasa tersebut sesuai dengan keinginan.

\section{METODOLOGI PENELITIAN}

Penelitian ini menggunakan Jumlah ampel sebesar menjadi 85 pendekatan kuantitatif, dengan rancangan desktiptif. Metode penelitian yang digunakan adalah metode survei penjelasan (explanatory survey method).

Pengambilan sampel dilakukan dengan menggunakan Accidental Sampling yaitu pengambilan sampel yang tidak dipandu oleh karakteristik yang jelas (Etikan \& Bala 2017: 2).

\section{HASIL DAN PEMBAHASAN}

\section{Pengujian Persyaratan Analisis}

\section{Uji Normalitas.}

Uji normalitas merupakan salah satu bagian dari uji persyaratan analisis data yang bertujuan untuk mengetahui data Berdasarkan penghitungan uji normalitas dengan menggunakan SPSS didapatkan hasil sebagai berikut:

tersebut berdistribusi normal atau tidak.

Tabel 1 Hasil Uji Normalitas

\begin{tabular}{|c|c|c|c|}
\hline Variabel & Nilai $\boldsymbol{\alpha}$ & Nilai Sig. & Kesimpulam \\
\hline$\xi_{1}$ & 0,05 & 0,122 & Normal \\
\hline$\xi_{2}$ & 0,05 & 0,200 & Normal \\
\hline$\eta_{1}$ & 0,05 & 0,093 & Normal \\
\hline$\eta_{2}$ & 0,05 & 0,102 & Normal \\
\hline
\end{tabular}

Sumber: Hasil SPSS 21

Berdasarkan tabel 1 menunjukkan bahwa besar dari 0,05 sehingga dapat disimpulkan semua variabel memiliki nilai sig lebih bahwa semua variabel berdistribusi normal. 


\section{Uji Homogenitas}

Uji homogenitas digunakan untuk menguji data variabel bersifat homogen atau heterogen dalam suatu populasi.
Berdasarkan penghitungan uji homgenitas dengan menggunakan SPSS didapatkan hasil sebagai berikut:

\section{Tabel 2 Hasil Uji Homogenitas}

\begin{tabular}{|c|c|c|c|}
\hline Variabel & Nilai $\boldsymbol{\alpha}$ & Nilai Sig. & Kesimpulam \\
\hline$\eta_{2}$ atas $\xi_{1}$ & 0,05 & 0,415 & Homogen \\
\hline$\eta_{2}$ atas $\xi_{2}$ & 0,05 & 0,164 & Homogen \\
\hline$\eta_{2}$ atas $\eta_{1}$ & 0,05 & 0,068 & Homogen \\
\hline$\eta_{1}$ atas $\xi_{1}$ & 0,05 & 0,410 & Homogen \\
\hline$\eta_{1}$ atas $\xi_{2}$ & 0,05 & 0,229 & Homogen \\
\hline
\end{tabular}

Sumber: Hasil SPSS 21

Berdasarkan tabel 2 menunjukkan bahwa $\eta_{2}$ atas $\xi_{1}, \eta_{2}$ atas $\xi_{2}, \eta_{2}$ atas $\eta_{1}, \eta_{1}$ atas $\xi_{1}$, dan $\eta_{1}$ atas $\xi_{2}$ memiliki nilai sig lebih besar dari 0,05 sehingga dapat dinyatakan bahwa semua data tersebut berasal dari variansi homogen.

\section{Uji Linieritas dan Regresi}

Uji linieritas dan regresi memiliki tujuan setiap variabel membentuk garis linier untuk mengetahui hubungan antara dan regresi yang signifikan atau tidak. variabel, dengan persyaratan bahwa

\section{Tabel 3 Hasil Uji Linieritas dan Regresi}

\begin{tabular}{|c|c|c|c|c|c|c|}
\hline \multirow{2}{*}{ Variabel } & \multicolumn{2}{|c|}{ Sig. Regresi } & \multirow{2}{*}{ Signifikansi regresi } & \multicolumn{2}{|c|}{ Lin. Regresi } & \multirow{2}{*}{ Linieritas regresi } \\
\cline { 2 - 3 } & $f_{\text {hitung }}$ & $\mathrm{f}_{\text {tabel }}$ & & & & \\
& & & $t_{\text {hitung }}$ & tabel & \\
\hline$\eta_{2}$ atas $\xi_{1}$ & 1,09 & 2,71 & Signifikan & 1,00 & 1,66 & Tidak Linier \\
\hline$\eta_{2}$ atas $\xi_{2}$ & 1,01 & 2,71 & Signifikan & 3,81 & 1,66 & Linier \\
\hline$\eta_{2}$ atas $\eta_{1}$ & 0,55 & 2,71 & Signifikan & 1,63 & 1,66 & Tidak Linier \\
\hline$\eta_{1}$ atas $\xi_{1}$ & 1,29 & 2,71 & Signifikan & 3,74 & 1,66 & Linier \\
\hline$\eta_{1}$ atas $\xi_{2}$ & 1,23 & 2,71 & Signifikan & 1,74 & 1,66 & Linier \\
\hline
\end{tabular}

Sumber: Hasil SPSS 21

Kriteria dalam pengujian linieritas dan regresi dalam penelitian ini pada Signifikan regresi memiliki nilai $\mathrm{f}_{\text {hitung }}<$

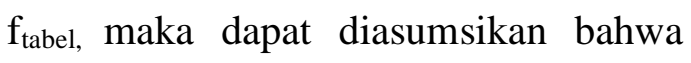
data tersebut berarti atau signifikan. dan untuk kriteria linieritas regresi jika memiliki nilai $t_{\text {hitung }}>t_{\text {tabel }}$ dapat disimpulkan bahwa data tersebut memiliki hubungan yang linier. 


\section{Hasil Perhitungan Koefesien T-value}

Setelah dilakukan pengujian analisis persyaratan, langkah selanjutnya adalah Koefisien seperti yang disajikan dalam perhitungan dan pengujian setiap jalur tabel berikut:

\section{Tabel 7 Hasil Koefisien Jalur}

\begin{tabular}{|c|c|c|c|c|c|}
\hline \multirow{2}{*}{ No } & \multirow{2}{*}{ Variabel } & \multicolumn{2}{|c|}{ Koefesien Jalur } & \multirow{2}{*}{ Hasil } & \multirow{2}{*}{ Kesimpulan } \\
\cline { 3 - 4 } & & SLF* & $\mathbf{t}_{\text {value }}$ & & \\
\hline 1 & $\eta_{2}$ atas $\xi_{1}$ & $-0,22$ & $-1,49$ & $\mathrm{H}_{0}$ diterima & Tidak Signifikan \\
\hline 2 & $\eta_{2}$ atas $\xi_{2}$ & 0,50 & 3,71 & $\mathrm{H}_{0}$ ditolak & Signifikan \\
\hline 3 & $\eta_{2}$ atas $\eta_{1}$ & 0,31 & 2,05 & $\mathrm{H}_{0}$ ditolak & Signifikan \\
\hline 4 & $\eta_{1}$ atas $\xi_{1}$ & 0,54 & 4,32 & $\mathrm{H}_{0}$ ditolak & Signifikan \\
\hline 5 & $\eta_{1}$ atas $\xi_{2}$ & $-0,19$ & $-1,58$ & $\mathrm{H}_{0}$ diterima & Tidak Signifikan \\
\hline
\end{tabular}

\section{Koefisien Jalur Sub-Struktur 1}

Model analisis koefisien jalur yang $\gamma_{11} \xi_{1}+\gamma_{12} \xi_{2}+\zeta_{1}$. Uji ini akan ditemukan, yaitu sub-struktur 1 memberikan pengambilan keputusan dinyatakan dalam bentuk persamaan $\eta_{1}=\quad$ untuk pengujian hipotesis 1 dan 2 .

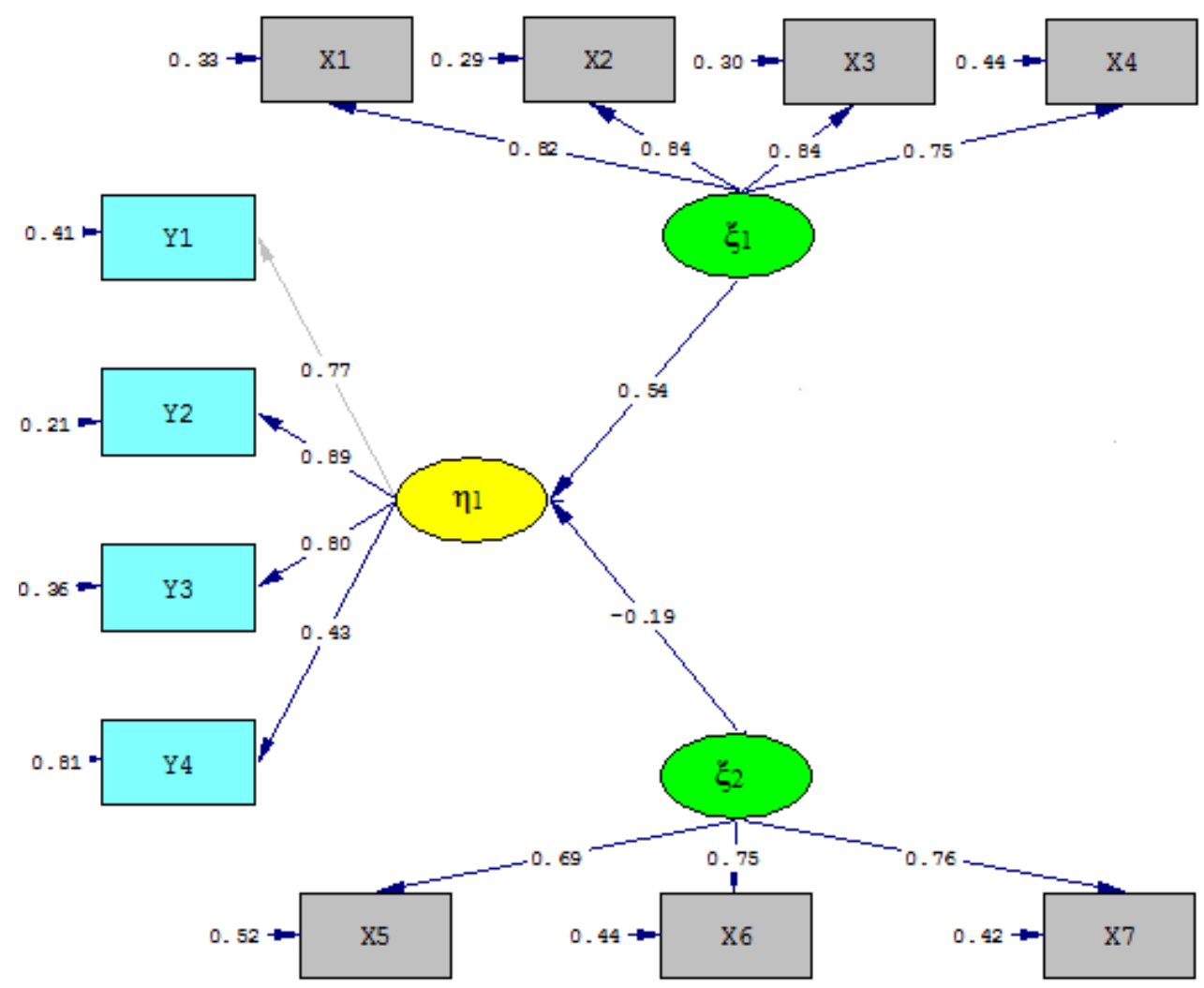

Chi-3quare $=92.52, \mathrm{df}=84, \mathrm{P}-\mathrm{value}=0.24599, \mathrm{RMSEA}=0.035$

\section{Gambar 1. Koefisien Jalur Sub-Struktur 1}


Berdasarkan pada hasil pengujian substruktur 1, koefisien jalur $\left(\gamma \eta_{1} \xi_{1}\right)$ sebesar 0,54 dan nilai $\mathrm{t}_{\text {value }}=4,32>\mathrm{t}_{\text {tabel }}(0,05: 85)$ $=1,66$, maka Ho ditolak dan koefisien jalur $\gamma \eta_{1} \xi_{1}$ signifikan. Koefisien jalur $\left(\gamma \eta_{1} \xi_{2}\right)$ sebesar $-0,19$ dan nilai $\mathrm{t}_{\text {value }}=-1,58<\mathrm{t}_{\text {tabel }}$ $(0,05: 85)=1,66$, maka Ho diterima dan koefisien jalur $\gamma \eta_{1} \xi_{2}$ tidak signifikan.

\section{Koefisien Jalur Sub-Struktur 2}

Model analisis koefisien jalur yang $\gamma_{21} \xi_{1}+\gamma_{22} \xi_{2}+\beta_{21} \eta_{1}+\zeta_{2}$. Uji ini akan ditemukan, yaitu sub-struktur 1 memberikan pengambilan keputusan dinyatakan dalam bentuk persamaan $\eta_{2}=$ untuk pengujian hipotesis 3, 4 dan 5 .

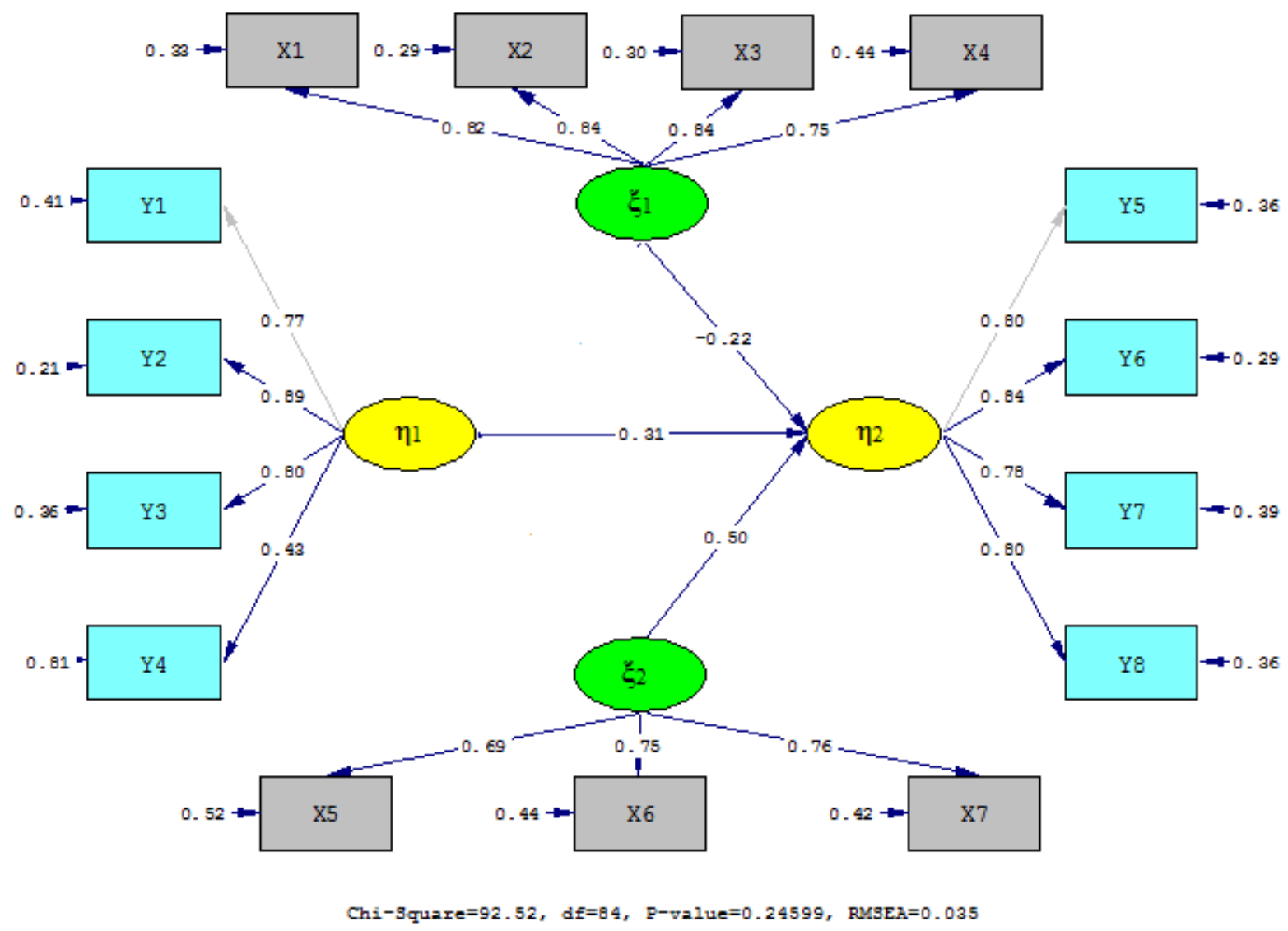

Gambar 2. Koefisien Jalur Sub-Struktur 2

Berdasarkan pada hasil pengujian substruktur 2, koefisien jalur $\left(\gamma \eta_{2} \xi_{1}\right)$ sebesar 0,22 dan nilai $\mathrm{t}_{\text {value }}=-1,49<\mathrm{t}_{\text {tabel }}(0,05: 85)$ = 1,66, maka Ho diterima dan koefisien jalur $\gamma \eta_{2} \xi_{1}$ tidak signifikan. Koefisien jalur $\left(\gamma \eta_{2} \xi_{2}\right)$ sebesar 0,50 dan nilai $t_{\text {value }}=3,71>$ $\mathrm{t}_{\text {tabel }}(0,05: 85)=1,66$, maka Ho ditolak dan koefisien jalur $\gamma \eta_{2} \xi_{2}$ signifikan. Koefisien jalur $\left(\beta \eta_{2} \eta_{1}\right)$ sebesar 0,31 dan nilai $t_{\text {value }}=$ 2,05 > $\mathrm{t}_{\text {tabel }}(0,05: 85)=1,66$, maka Ho ditolak dan koefisien jalur $\beta \eta_{2} \eta_{1}$ signifikan. Berdasarkan pada hasil perhitungan

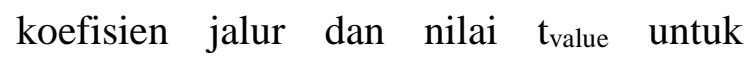
keperluan pengujian hipotesis, 
menunjukkan bahwa nilai standardized loading factor koefisien jalur $\left(\gamma \eta_{2} \xi_{2}, \beta \eta_{2} \eta_{1}\right.$, dan $\gamma \eta_{1} \xi_{1}$ ) lebih besar 0,05 dan tvalue lebih besar 1,66, sehingga Ho ditolak dan signifikan. Sedangkan dua koefisien jalur $\left(\gamma \eta_{2} \xi_{1}\right.$ dan $\left.\gamma \eta_{1} \xi_{2}\right)$ lebih kecil 0,05 dan tvalue lebih kecil 1,66, sehingga Ho diterima dan tidak signifikan. Secara keseluruhan diagram standardized solution pada setiap variabel melalui hubungan struktural program linier yang diuraikan sebagai berikut:

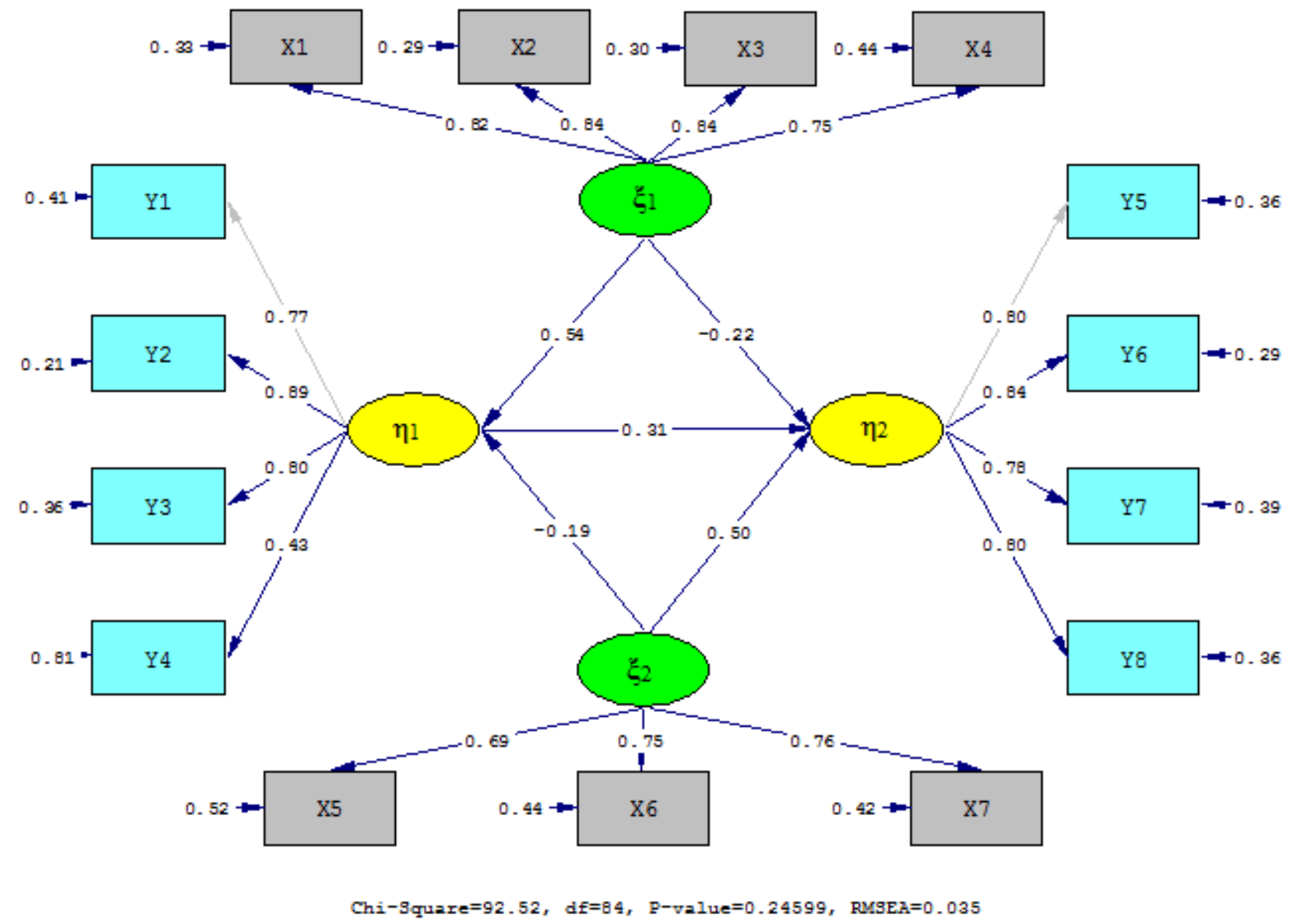

Gambar 3. Diagram Jalur Standardized Solution

Berdasarkan pada gambar 3, diagram jalur standardized solution, di samping pengaruh langsung, ada pengaruh total dan tidak langsung (inderect effect) antara variabel eksogen $(\xi)$ dengan endogen variabel $(\eta)$. Berdasarkan output hubungan struktural linear tentang standardized effect total menunjukkan bahwa: (1) nilai pengaruh (effect) $\xi_{1} \xi_{2}$ dan $\eta_{1}$ ke $\eta_{2}$ sama dengan nilai pengaruh langsung (direct effect) masingmasing variabel tersebut, karena tidak dimediasi oleh variabel lain (variabel intervening), (2) nilai pengaruh (total effect) variabel $\xi_{1}$ dan $\xi_{2}$ ke $\eta_{1}$ juga sama dengan nilai pengaruh langsung (direct effect) masing-masing variabel tersebut, karena tidak dimediasi oleh variabel lain (variabel intervening), (3) pengaruh tidak langsung 
(inderect effect) variabel $\xi_{1}$ ke $\eta_{2}$ sebesar $0,54 \times 0,31=0,1674$ karena adanya variabel lain (variabel intervening) yaitu $\eta_{1}$ sebesar 0,22 sedangkan total pengaruhnya adalah $0,22+0,1674=0,3874$, dan (4) pengaruh tidak langsung (inderect effect) variabel $\xi_{2}$ ke $\eta_{2}$ sebesar $0,19 \times 0,31=0,058$ karena adanya variabel lain (variabel intervening) yaitu $\eta_{1}$ sebesar 0,50 sedangkan total pengaruhnya adalah $0,50+0,058=0,558$.

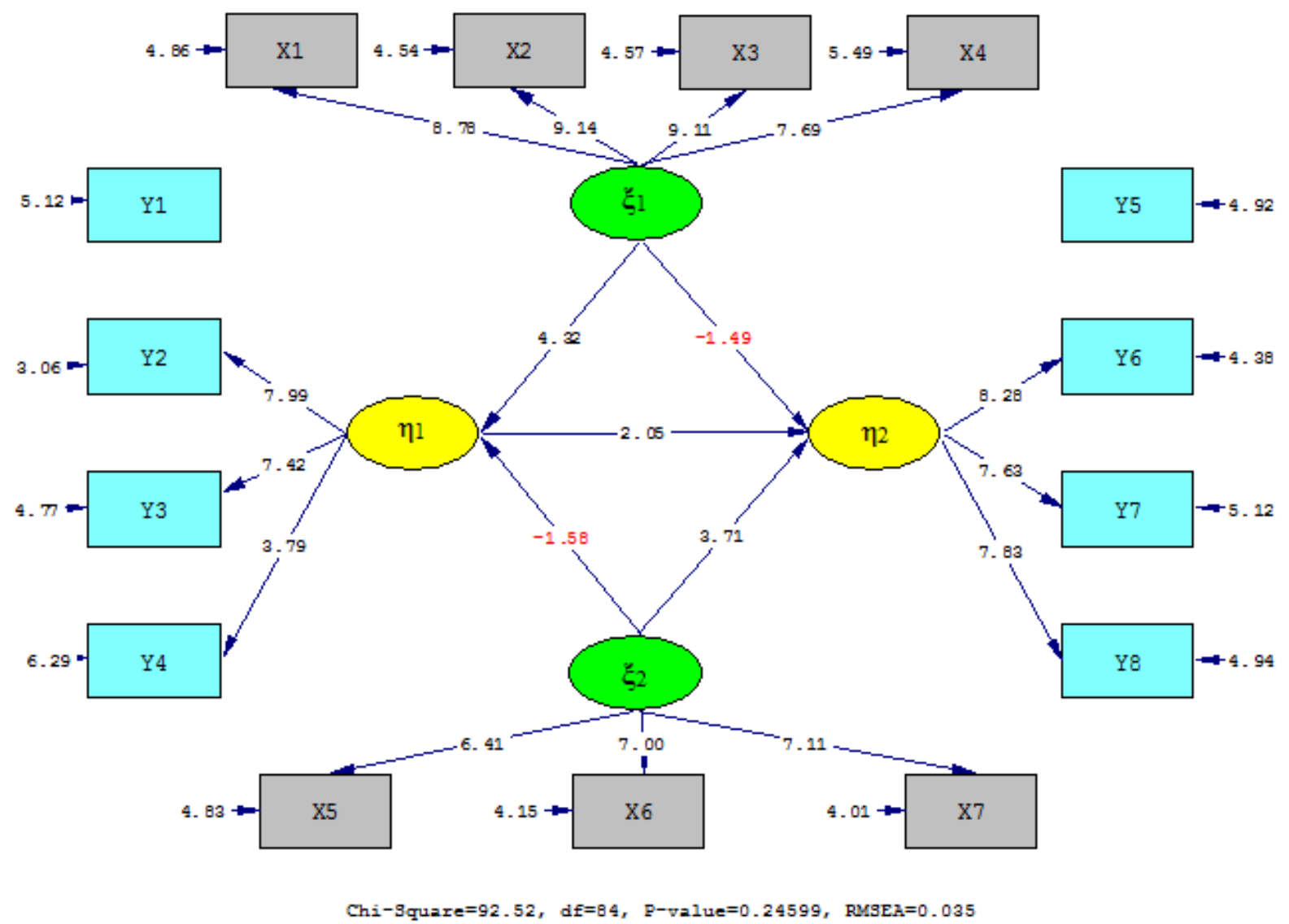

Gambar 4. Diagram Jalur T-value

\section{Uji Kecocokan Keseluruhan Model}

Berdasarkan pada hasil pengujian SEM dengan LISREL, hasil uji goodness of fit dalam Structural equation modelling (SEM) dapat dilihat pada tabel berikut:

Tabel 8 Rangkuman Hasil Uji Kecocokan Model (Goodness of Fit)

\begin{tabular}{|c|c|c|c|c|}
\hline No & Indeks & Hasil & $\begin{array}{c}\text { Nilai Yang } \\
\text { Direkomendasikan }\end{array}$ & Kesimpulan \\
\hline 1 & Probabilitas $X^{2}$ & 0,24599 & $>0,05$ & Good Fit \\
\hline 2 & $X^{2} / d f$ & 1,19 & $<5$ & Good fit \\
\hline 3 & $R M S E A$ & 0,035 & $<0,08$ & Good fit \\
\hline 4 & AGFI & 0,82 & $<0,90$ & Marginal fit \\
\hline
\end{tabular}




\begin{tabular}{|c|c|c|c|c|}
\hline No & Indeks & Hasil & $\begin{array}{c}\text { Nilai Yang } \\
\text { Direkomendasikan }\end{array}$ & Kesimpulan \\
\hline 5 & GFI & 0,87 & $<0,90$ & Marginal fit \\
\hline 6 & CFI & 0,98 & $>0,90$ & Good fit \\
\hline 7 & NFI & 0,89 & $<0,90$ & Marginal fit \\
\hline 8 & NNFI & 0,97 & $>0,90$ & Good fit \\
\hline 9 & IFI & 0,98 & $>0,90$ & Good fit \\
\hline 10 & RFI & 0,86 & $<0,90$ & Marginal fit \\
\hline 11 & ECVI & 1,96 & $<5$ & Good fit \\
\hline
\end{tabular}

Sumber: Hasil Pengolahan Data dengan LISREL

Berdasarkan hasil dari output Lisrel, uji kecocokan keseluruhan model menggunakan uji $\chi^{2}$ (chi square) yang diperoleh dari nilai Weighted Least Squares chi-square 100,24 dengan pvalue $0,24599<0,05$ sehingga dapat disimpulkan bahwa hasil pengujian $\chi^{2}$ secara keseluruhan cocok. Selain itu, perbandingan nilai $\chi 2$ dengan degree of fredom $(\chi 2 / \mathrm{df})$ yaitu $100,24 / 84=1,19<$ 0,05 sehingga dapat disimpulkan bahwa dengan mengendalikan kompleksitas model (yang diproksi dengan jumlah

Pengaruh Langsung Positif Variabel $\xi_{1}$ Terhadap Variabel $\boldsymbol{\eta}_{2}$

Hipotesis 1 terdapat pengaruh langsung positif $\xi_{1}$ terhadap $\eta_{2}$. Hasil penelitian ini menunjukkan bahwa terdapat pengaruh langsung positif variabel $\xi_{1}$ terhadap variabel $\eta_{2}$ dengan nilai $t_{\text {value }}>t_{\text {tabel }}$ yaitu - tekanan kebebasan), model sebenarnya memiliki kecocokan yang cukup baik.

Uji selanjutnya adalah RMSEA menunjukkan lebih kecil dari 0,08, sehingga dapat disimpulkan bahwa model memiliki kecocokan yang baik. Selanjutnya AGFI, GFI, NFI dan RFI yang menunjukkan hasil tes kurang dari 0,90, sehingga dapat disimpulkan bahwa model memiliki kecocokan yang kurang baik, sedangkan CFI, NNFI, IFI, dan ECVI menunjukkan hasil uji lebih dari 0,90 sehingga dapat disimpulkan bahwa model memiliki kecocokan yang baik.

$1,49<1,66$, maka dapat disimpulkan bahwa hipotesis 1 ditolak.

Pengaruh Langsung Positif Variabel $\xi_{2}$ Terhadap Variabel $\eta_{2}$ 
Hipotesis 2 terdapat pengaruh langsung positif $\xi_{2}$ terhadap $\eta_{2}$. Hasil penelitian ini menunjukkan bahwa terdapat pengaruh langsung positif variabel $\xi_{2}$ terhadap variabel $\eta_{2}$ dengan nilai $t_{\text {value }}>t_{\text {tabel }}$ yaitu $3,71>1,66$, maka dapat disimpulkan bahwa hipotesis 2 diterima.

\section{Pengaruh Langsung Positif Variabel $\eta_{1}$ Terhadap Variabel $\boldsymbol{\eta}_{2}$}

Hipotesis 3 terdapat pengaruh langsung positif $\eta_{1}$ terhadap $\eta_{2}$. Hasil penelitian ini menunjukkan bahwa terdapat pengaruh langsung positif variabel $\eta_{1}$ terhadap variabel $\eta_{2}$ dengan nilai $t_{v a l u e}>t_{\text {tabel }}$ yaitu 2,05 > 1,66, maka maka dapat disimpulkan bahwa hipotesis 3 diterima.

\section{Pengaruh Langsung Positif Variabel $\xi_{1}$ Terhadap Variabel $\eta_{1}$}

Hipotesis 4 terdapat pengaruh langsung positif $\xi_{1}$ terhadap $\eta_{1}$. Hasil penelitian ini menunjukkan bahwa terdapat pengaruh langsung positif variabel $\xi_{1}$ terhadap variabel $\eta_{1}$ dengan nilai $t_{\text {value }}>t_{\text {tabel }}$ yaitu 4,32>1,66, maka dapat disimpulkan bahwa hipotesis 4 diterima.

Pengaruh Langsung Positif Variabel $\xi_{2}$ Terhadap Variabel $\boldsymbol{\eta}_{1}$

Hipotesis 5 terdapat pengaruh langsung positif $\xi_{2}$ terhadap $\eta_{1}$. Hasil penelitian ini menunjukkan bahwa terdapat pengaruh langsung positif variabel $\xi_{2}$ terhadap variabel $\eta_{1}$ dengan nilai $t_{\text {value }}>t_{\text {tabel }}$ yaitu 1,58 > 1,66, maka dapat disimpulkan bahwa hipotesis 5 diterima.

\section{Simpulan Dan Saran}

Berdasarkan hasil dan pembahasan maka dapat diperoleh simpulan bahwa courtesy tidak memiliki pengaruh langsung positif terhadap loyalitas nasabah, Daya Tanggap memiliki pengaruh langsung positif terhadap loyalitas nasabah, kepuasan nasabah memiliki pengaruh langsung positif terhadap loyalitas nasabah, courtesy memiliki pengaruh langsung positif terhadap kepuasan nasabah dan Daya Tanggap tidak memiliki pengaruh langsung terhadap kepuasan nasabah.

Sikap sopan dan santun yang ditunjukkan karyawan kepada nasabah atau pelanggan tidak mempengaruhi komitmen pelanggan dalam menggunakan kembali atau melakukan pembelian ulang produk atau jasa yang dihasilkan perusahaan tersebut. Karyawan atau pegawai yang melayani pelanggan dengan cepat dan tepat waktu, dapat menimbulkan rasa komitmen pada diri pelanggan untuk terus menggunakan merek tersebut sehingga pelanggan akan melakukan pembelian ulang dan akan merekomendasikan kepada orang lain yang akan menguntungkan perusahaan. 
Courtesy atau kesopanan harus ditingkatkan, karena dengan meningkatkan sikap sopan santun karyawan dalam melayani nasabah atau pelanggan untuk memenuhi kebutuhan nasabah. Untuk meningkatkan loyalitas nasabah, maka hal yang harus dilakukan dengan memberikan pelayanan yang berkualitas, pelayanan yang mudah, pelayanan yang cepat dan tepat waktu sehingga dapat menimbulkan kepuasan nasabah dan nasabah akan merekomendasikan kepada orang lain untuk menggunakan produk atau jasa yang dihasilkan.

\section{DAFTAR PUSTAKA}

Abd Ghani, M., Rahi, S., Yasin, N. M., \& Alnaser, F. M. (2017). Adoption of internet banking: extending the role of technology acceptance model (TAM) with e-customer service and customer satisfaction. World Applied Sciences Journal, 35(9), 1918-1929.

Al-Azzam, A. F. M. (2015). The impact of service quality dimensions on customer satisfaction: A field study of Arab bank in Irbid city, Jordan. European Journal of Business and Management, 7(15), 45-53.

Al-Mhasnah, A., Salleh, F., Afthanorhan, A., \& Ghazali, P. J. M. S. L. (2018). The relationship between services quality and customer satisfaction among Jordanian healthcare sector. Management Science Letters, 8(12), 1413-1420.
Basari, M. A. M. D., \& Shamsudin, M. F. (2020). Does Customer Satisfaction Matters?. Journal of Undergraduate Social Science and Technology, 2(1).

Çavuş, M. F., \& Develi, A. (2017). Ethical Climate and Organizational Citizenship

Behaviour. International Journal of Human Resource Studies, 7(1), 38-51.

Eisenberg, A., Davidova, J., Ignatjeva, S., \& Rauckiene-Michaelsson, A. (2018). Assessing The Interrelations Between Organizational Learning Culture And Organizational Citizenship Behavior In The Public Sector. Tiltai, 80(2), 85-98.

Etikan, I., \& Bala, K. (2017). Sampling and sampling methods. Biometrics \& Biostatistics International Journal, 5(6), 00149.

Felix, R. (2017). Service quality and customer satisfaction in selected banks in Rwanda. Journal of Business \& Financial Affairs, 6(1), 1-11.

Getahun, D. A. (2018). Common Leadership Practices and Organizational Citizenship Behavior: A study of North West Region Ethiopian Electric Power Corporation. Management Today, 8(2), 145-148.

Hu, K. C., \& Huang, M. C. (2011). Effects of service quality, innovation and corporate image on customer's satisfaction and loyalty of air cargo terminal. International Journal of Operations Research, 8(4), 36-47.

Leninkumar, V. (2017). The relationship between customer satisfaction and customer trust on customer loyalty. International Journal of 
Academic Research in Business and Social Sciences, 7(4), 450-465.

Muhamad, Yunus, Nor Sara Nadia., Bojei, Jamil., \& Wan Rashid, Wan Edura. (2013) Service quality towards customer loyalty in Malaysia's domestic low cost airline service. International Journal of e-Education, e-Business, $e$-Management and e-Learning, 3 (4). 333-336.

Omar, M. S., Ariffin, H. F., \& Ahmad, R. (2016). Service quality, customers' satisfaction and the moderating effects of gender: A study of Arabic restaurants. Procedia-Social and Behavioral Sciences, 224, 384-392.

Othman, B., Harun, A., Rashid, W., \& Ali, R. (2019). The impact of Umrah service quality on customer satisfaction towards Umrah travel agents in Malaysia. Management Science Letters, 9(11), 1763-1772.

Özdemir, Y., \& Ergun, S. (2015). The relationship between organizational socialization and organizational citizenship behavior: the mediating role of person-environment fit. Procedia-Social and Behavioral Sciences, 207(20), 432443.

Rai, A. K., \& Medha, S. (2013). The antecedents of customer loyalty: An empirical investigation in life insurance context. Journal of Competitiveness, 5(2), 139-163.

Rizan, M., Warokka, A., \& Listyawati, D. (2014). Relationship marketing and customer loyalty: do customer satisfaction and customer trust really serve as intervening variables?. Journal of Marketing Research \& Case Studies, 2014, 112.

Setiawan, H., \& Sayuti, A. J. (2017). Effects of service quality, customer trust and corporate image on customer satisfaction and loyalty: An assessment of travel agencies customer in South Sumatra Indonesia. IOSR Journal of Business and Management, 19(5), 31-40.

Srivastava, M., \& Rai, A. K. (2018). Mechanics of engendering customer loyalty: A conceptual framework. IIMB management review, 30(3), 207-218.

Suharto, \& Ardhiansyah. (2019). Customer Loyalty Measurement Using Burnout and Confidence with Organizational Citizenship Behaviour as Antecedents Variable, The Jounal of Social Science Reseach. 5. 1016-1024.

Tambe, S., \& Shanker, M. (2014). A Study of Organizational Citizenship Behaviour (OCB) and Its Dimensions: A Literature Review. International Research Journal of Business and Management, 1, 6773.

Yin, Ong \& Hee, Ong \& Mahmood, Rahamah \& Hamli, Mohd. (2018). Organizational Citizenship Behaviour and Turnover Intention among Generation Y in Malaysia. International Journal of Academic Research in Business and Social Sciences, 8, 690-701. 